University of South Carolina

Scholar Commons

$3-6-2014$

\title{
A Reactor Model for Hydrogen Generation from Sodium Borohydride and Water Vapor
}

Lin Yu

Michael A. Matthews

University of South Carolina - Columbia, matthews@cec.sc.edu

Follow this and additional works at: https://scholarcommons.sc.edu/eche_facpub

Part of the Chemical Engineering Commons

\section{Publication Info}

Published in International Journal of Hydrogen Energy, Volume 39, Issue 8, 2014, pages 3830-3836.

( ) International Journal of Hydrogen Energy 2014, Elsevier.

Yu, Lin \& Matthews, M. A. (2014). A Reactor Model for Hydrogen Generation from Sodium Borohydride and Water Vapor. International Journal of Hydrogen Energy 2014, 39 (8), 3830-3836. http://dx.doi.org/ 10.1016/j.ijhydene.2013.12.147

This Article is brought to you by the Chemical Engineering, Department of at Scholar Commons. It has been accepted for inclusion in Faculty Publications by an authorized administrator of Scholar Commons. For more information, please contact digres@mailbox.sc.edu. 


\title{
A reactor model for hydrogen generation from sodium borohydride and water vapor
}

\author{
Lin Yu, Michael A. Matthews* \\ Department of Chemical Engineering, Swearingen Engineering Center, University of South Carolina, 301 Main Street, \\ Columbia, SC 29208, USA
}

\section{A R T I C L E I N F O}

\section{Article history:}

Received 13 July 2013

Received in revised form

20 December 2013

Accepted 24 December 2013

Available online 22 January 2014

\section{Keywords:}

Hydrogen storage

Sodium borohydride

Water vapor

Reactor model

\begin{abstract}
A B S T R A C T
This paper reports new data on the production of hydrogen from water vapor plus $\mathrm{NaBH}_{4}$, or $\mathrm{NaBH}_{4}+10 \% \mathrm{CoCl}_{2}$. Data were collected with the aid of an isothermal semi-batch reactor with in-situ $\mathrm{H}_{2}$ rate measurement. The reaction of $\mathrm{NaBH}_{4}$ to generate $\mathrm{H}_{2}$ proceeds via three steps: deliquescence, dissolution and reaction. The deliquescence regime of $\mathrm{NaBH}_{4}$ in the presence of 10 weight percent $\mathrm{CoCl}_{2}$ is defined. The $\mathrm{H}_{2}$ yield is quantified at various reaction conditions (reaction temperature $70-120{ }^{\circ} \mathrm{C}$, relative humidity $31-69 \%$ ). $\mathrm{CoCl}_{2}$ significantly accelerates the rate of $\mathrm{H}_{2}$ production compared to deliquescence + reaction of pure $\mathrm{NaBH}_{4}$. It is also found that a combination of high temperature and high relative humidity contributes to high $\mathrm{H}_{2}$ rate and yield, and either of the two factors dominates the reaction at different conditions. A two-part reactor model accounting for the mechanism of the steam hydrolysis by $\mathrm{NaBH}_{4}$ is developed. The model captures the dissolution + reaction step as well as reaction-only step and was validated by experimental data.

Copyright $\odot$ 2014, Hydrogen Energy Publications, LLC. Published by Elsevier Ltd. All rights
\end{abstract}

reserved.

\section{Introduction}

Practical means of hydrogen production and storage are essential to enable the goal of using hydrogen as an energy carrier to address the public concern of the depletion of fossil fuel and environmental pollution [1-3]. The specific means of hydrogen storage will depend on the application, and so a variety of approaches are being considered for both niche and large-scale applications. Many investigations are aimed at discovering and evaluating the most effective hydrogen storage materials. Use of compressed gaseous or liquefied $\mathrm{H}_{2}$ [4], carbon nanotubes [5], metal organic frameworks [6] and chemical methods [7] have been actively studied. For portable applications, the first three methods have disadvantages such as low volumetric and gravimetric density, high energy consumption, and rigorous operating conditions [4-6]. However, chemical storage with complex hydrides, for example, $\mathrm{NaBH}_{4}, \mathrm{LiBH}_{4}$, and $\mathrm{Mg}\left(\mathrm{BH}_{4}\right)_{2}$ etc., have been found to be promising candidates for portable applications because of their high gravimetric hydrogen storage capacity (over $10 \mathrm{wt} . \%)$ and near ambient operating conditions [8,9]. Among them, $\mathrm{NaBH}_{4}$ is one of the most promising because of its stability, low cost, non-flammability, non-toxicity, and high theoretical storage density [10]. The Department of Energy keeps the recommendation for $\mathrm{NaBH}_{4}$ as one of the best candidates for application in portable devices, though it has been down selected for on-board use [11].

Most work on hydrolysis of $\mathrm{NaBH}_{4}$ [12-16] has been done in aqueous solutions, and most recent work has focused on supported metal or metal salt catalysts. Meanwhile, there has been only limited study on another reaction pathway, so-

\footnotetext{
* Corresponding author. Tel.: +1 803777 0556; fax: +1 8037779597.

E-mail address: mamatthe@mailbox.sc.edu (M.A. Matthews). 0360-3199/\$ - see front matter Copyright @ 2014, Hydrogen Energy Publications, LLC. Published by Elsevier Ltd. All rights reserved. http://dx.doi.org/10.1016/j.ijhydene.2013.12.147
} 
called "steam hydrolysis", i.e. reacting $\mathrm{NaBH}_{4}$ with water vapor. One advantage of this reaction pathway is that high $\mathrm{H}_{2}$ production rates and yield can be achieved by controlling temperature and humidity [17]. Another advantage is that one can potentially reduce the excess water that present in aqueous reaction by using water vapor, which has the potential to improve the storage density for the whole system. Previously, Aiello [17] and Beaird [21] have focused on experimental screening and Marrero [18-20] focused on physical characterization of the borate products. Aiello found that a $\mathrm{H}_{2}$ yields up to $90 \%$ can be achieved even without catalyst at $110^{\circ} \mathrm{C}$ [17]. Marrero found that reactant physical form, such as a thin film, can improve the $\mathrm{H}_{2}$ production rate [19] and different metaborate products are obtained at different reaction temperatures [18]. Beaird [21] determined the deliquescence regime under which reaction temperature and relative humidity were favored for pure $\mathrm{NaBH}_{4}$ hydrolysis.

Despite the previous efforts on the steam hydrolysis, no detailed quantitative reports have been published on the kinetics of the steam hydrolysis reaction. Because knowledge of the $\mathrm{H}_{2}$ release rate and yield is essential for application in a fuel cell system, we have investigated the apparent $\mathrm{H}_{2}$ generation kinetics in the vapor deliquescence pathway, using both pure $\mathrm{NaBH}_{4}$ and $\mathrm{NaBH}_{4}$ mixed with a metal salt catalyst, anhydrous cobalt(II) chloride. Herein we report a greatly improved hydrogen production rate and yield when $\mathrm{CoCl}_{2}$ is added in the steam reaction. The deliquescence behavior of the mixture and its effect on the $\mathrm{H}_{2}$ rate are discussed. Quantification of the effect of temperature and relative humidity on the $\mathrm{H}_{2}$ yield is reported. Finally, we propose a reaction rate model incorporating deliquescence, dissolution and reaction as observed in the steam hydrolysis pathway.

\section{Experimental method}

An isothermal semi-batch reactor combined with a visualization device was used for the study of sodium borohydride reacting with water vapor. Fig. 1 shows the schematic of the reactor assembly, originally designed by Beaird [21], modified for this study. The reactor is a 1 inch diameter quartz tube, which was filled with $0.2 \pm 0.03 \mathrm{~g}$ of anhydrous $\mathrm{NaBH}_{4}$ powder (98\%, Alfa Aesar) for each run. In experiments with mixtures, 10 wt.\% anhydrous $\mathrm{CoCl}_{2}$ powder was added. These two powders were mixed together in a mortar prior to loading in the reactor. To prevent loss of the powder and unwanted interactions with moisture in air, glass wool was placed in both ends of the tube. All solid mixing and loading was performed in a controlled atmosphere glove box. A Hawkeye classic precision borescope with video camera was positioned above the reactor through an opening in the top oven wall. A fiber optic illuminator (Fiber-Lite Model 3100 by Dolan Jenner Industries Inc.) was introduced through a $1 \mathrm{~cm}$ diameter opening on the right side of the oven wall. The use of the illuminator coupled with video camera ensured an enhanced continuous in-situ visualization of the reaction.

To prevent pre-absorption of water during startup, the reaction system was purged with ultrahigh purity nitrogen (National Welders) while the oven was heated to the reaction temperature. The desired mole fraction of water was achieved by flowing the nitrogen carrier gas at 0.1 SLPM (standard liter per minute) through a heated $500 \mathrm{~mL}$ saturator (refer to Fig. 1) containing deionized water (17 $\mathrm{M} \Omega \mathrm{cm}$ resistivity) from a Barnstead system. The nitrogen flow rate was controlled with a Teledyne mass flow meter. The saturated nitrogen was directed through a pre-heating coil inside the oven to equilibrate to the reaction temperature. The relative humidity of the humid nitrogen stream entering the reactor was determined from the mole fraction of water exiting the saturator and the pressure (1 atm) and temperature of reactor. Blank tests were performed to demonstrate water balance closure within $5 \%$.

The hydrolysis experiments were carried out over a range of temperatures between 40 and $120{ }^{\circ} \mathrm{C}$. We allowed 5-15 min per experiment to observe the onset of deliquescence and $\mathrm{H}_{2}$ evolution. If no water uptake was observed during this interval, the reaction temperature was decreased, i.e. the relative humidity in the reactor was increased, and the system was again allowed to equilibrate. This process was continued until water sorption on the $\mathrm{NaBH}_{4}+\mathrm{CoCl}_{2}$ mixture was visually observed. Hydrogen evolution began shortly after

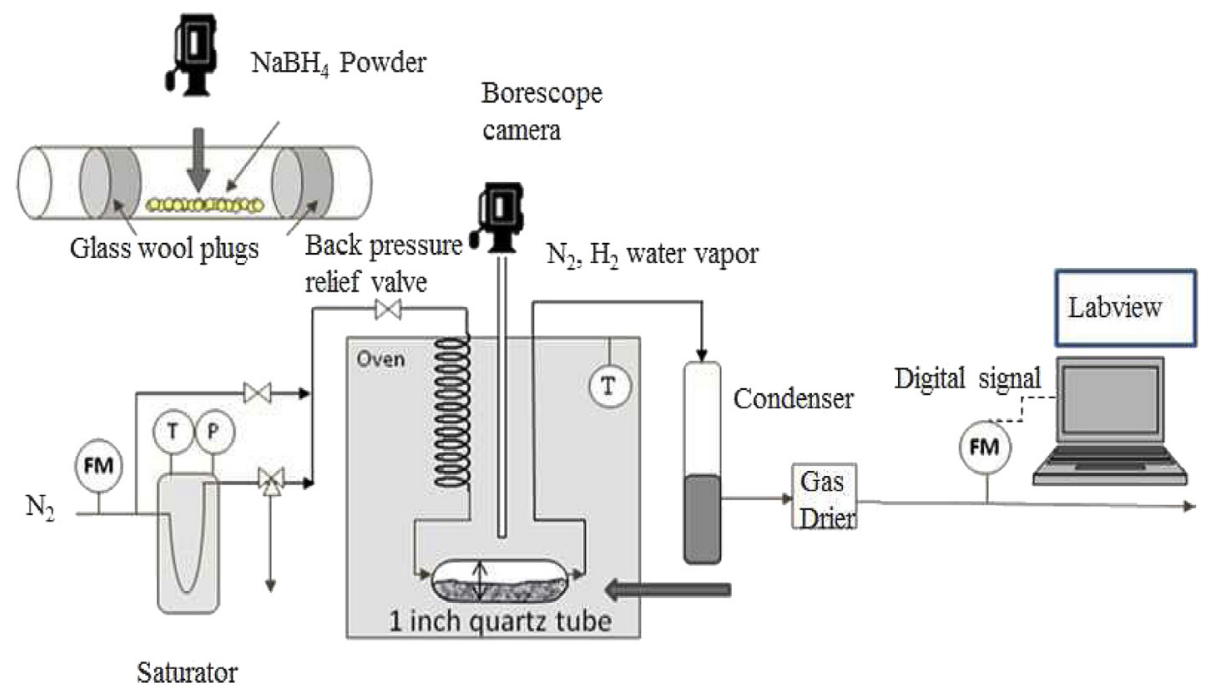

Fig. 1 - Isothermal semi-batch reactor with in-situ $\mathrm{H}_{2}$ rate measurement. 
observation of water sorption. Humid gas $\left(\mathrm{N}_{2}+\mathrm{H}_{2} \mathrm{O}+\mathrm{H}_{2}\right)$ from the reactor passed through a condenser, then a desiccant tube. The hydrogen generation rate was quantified by measuring the total mass flow rate after the desiccant, and subtracting the inlet $\mathrm{N}_{2}$ flow rate. The inlet and outlet flow meters were controlled by Labview.

\section{Hydrogen production from steam hydrolysis}

Fig. 2 shows the effect of adding $\mathrm{CoCl}_{2}$ to $\mathrm{NaBH}_{4}$ for the steam hydrolysis for $\mathrm{H}_{2}$. It is known that $\mathrm{CoCl}_{2}$ is a catalyst for aqueous hydrolysis of $\mathrm{NaBH}_{4}$ [16]. In the present work, water first deliquesces on the surface of the solid mixture, followed by dissolution. Therefore, $\mathrm{CoCl}_{2}$ is still a liquid phase catalyst. It is seen in Fig. 2 that the hydrolysis for $0.20 \mathrm{~g} \mathrm{NaBH}_{4}$ without $\mathrm{CoCl}_{2}$ takes 110 min to reach $0.4 \mathrm{~L}$ of $\mathrm{H}_{2}$, near $80 \%$ the yield. By contrast, it takes only $45 \mathrm{~min}$ to reach $100 \%$ yield in the presence of $10 \%$ by weight $\mathrm{CoCl}_{2}$. Therefore, $\mathrm{CoCl}_{2}$ significantly increases the $\mathrm{H}_{2}$ production yield and rate in steam hydrolysis.

To further elucidate the pathway of steam hydrolysis, the deliquescence relative humidity for water vapor on pure $\mathrm{NaBH}_{4}$, and on a mixture of $\mathrm{NaBH}_{4}$ with $10 \% \mathrm{CoCl}_{2}$ was measured. Table 1 shows the deliquescence relative humidity (DRH). The right column represents the DRH for pure $\mathrm{NaBH}_{4}$ taken from Beaird's work [21] and the left column represents $\mathrm{DRH}$ for the mixture measured in this work. It is seen that over the range of $y_{\mathrm{H}_{2} \mathrm{O}}$ (water mole fraction), the deliquescence temperature decreases for the mixture compared to that for pure $\mathrm{NaBH}_{4}$. That is to say, adding $\mathrm{CoCl}_{2}$ increases the DRH (the humidity required for the onset of deliquescence).

The increase in deliquescence relative humidity for the solid electrolyte mixture merits some explanation. The theory of so-called "deliquescence lowering" in binary electrolytes has been presented in detail by Wexler and Seinfeld [24]. This

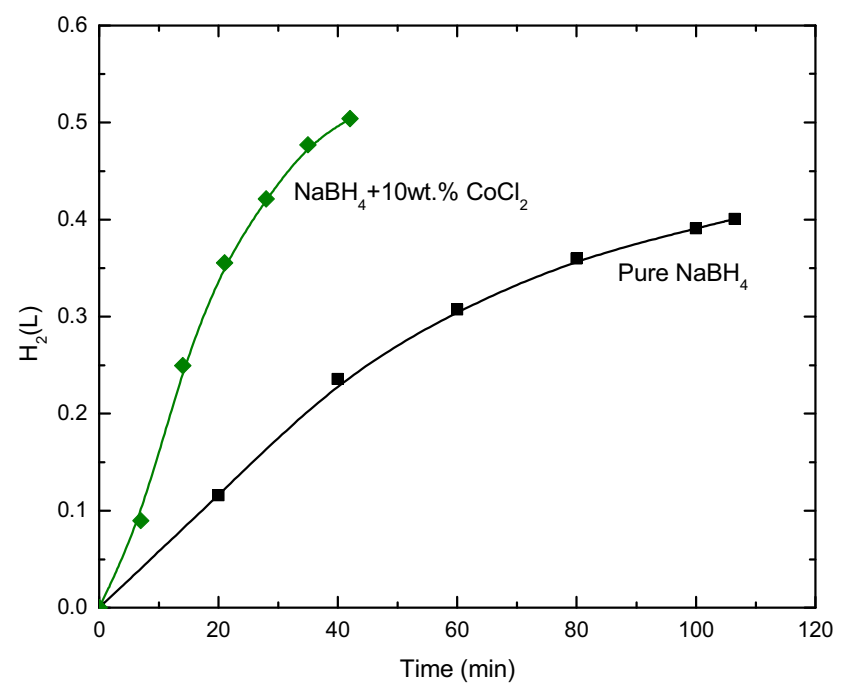

Fig. $2-\mathrm{H}_{2}$ production from pure $\mathrm{NaBH}_{4}$ and $\mathrm{NaBH}_{4}+10 \mathrm{wt} . \% \mathrm{CoCl}_{2}\left(\mathrm{~T}_{\text {reaction }}=90{ }^{\circ} \mathrm{C}\right.$, Relative humidity $=69 \%$ ).
Table 1 - Deliquescence relative humidity at ambient pressure for $\mathrm{NaBH}_{4}$ and $\mathrm{NaBH}_{4}+10 \% \mathrm{CoCl}_{2}$.

\begin{tabular}{lccccccc}
$\mathrm{CoCl}_{2}+\mathrm{NaBH}_{4}$ & & & & \multicolumn{3}{c}{ Pure $\mathrm{NaBH}_{4}$} \\
\cline { 1 - 2 } \cline { 6 - 7 } $\begin{array}{l}\text { Temperature } \\
\left({ }^{\circ} \mathrm{C}\right)\end{array}$ & $\mathrm{y}_{\mathrm{H}_{2} \mathrm{O}}$ & $\begin{array}{c}\mathrm{RH} \\
\%\end{array}$ & & $\begin{array}{c}\text { Temperature } \\
\left({ }^{\circ} \mathrm{C}\right)\end{array}$ & $\mathrm{y}_{\mathrm{H}_{2} \mathrm{O}}$ & $\begin{array}{c}\mathrm{RH} \\
\%\end{array}$ \\
\hline 40 & 0.04 & 54.9 & & 50 & 0.03 & 20.5 \\
60 & 0.09 & 45.8 & & 70 & 0.06 & 30.5 \\
70 & 0.13 & 40.6 & & 90 & 0.12 & 17.3 \\
85 & 0.19 & 33.3 & & 105 & 0.30 & 25.2 \\
100 & 0.35 & 35.0 & & 110 & 0.42 & 29.7 \\
100 & 0.44 & 44.0 & & 120 & 0.50 & 25.5 \\
110 & 0.55 & 38.9 & & 135 & 0.66 & 21.4 \\
120 & 0.74 & 37.8 & & 155 & 0.80 & 14.9 \\
\hline
\end{tabular}

theory establishes that a binary mixture of deliquescing electrolytes will exhibit a minimum in the DRH at a certain composition, the "eutonic" composition (see Fig. 3). According to the theory, the DRH is a non-linear function of the composition of the two electrolytes, and the minimum DRH for the mixture must fall beneath the lowest DRH of the pure components [24]. However, in region 2 of Fig. 3, the mixture DRH may be between that of the single electrolytes. Indeed, the theory illustrated in Fig. 3 (which is modeled after the figure shown by Carroll et al. [25]) shows that the mixture DRH may lie above a straight line connecting the pure component DRH. In Fig. 3, curves 1 and 2 illustrate the deliquescence relative humidity of an electrolyte mixture on either side of the eutonic point. Pure $\mathrm{CoCl}_{2}$ has a deliquescence relative humidity of $80 \%$ at $25^{\circ} \mathrm{C}$ [22] and pure $\mathrm{NaBH}_{4}$ has a DRH of $26 \%$ [3]. We speculate that the eutonic composition for $\mathrm{CoCl}_{2}+\mathrm{NaBH}_{4}$ is greater than $90 \% \mathrm{NaBH}_{4}$, thus the $10 \% \mathrm{CoCl}_{2}$ mixture investigated in this work lies on curve 1, as suggested in Fig. 3. Additional measurements over the entire composition range would be warranted.

In all our experiments, we observed a lag time between the introduction of water vapor and the onset of hydrogen

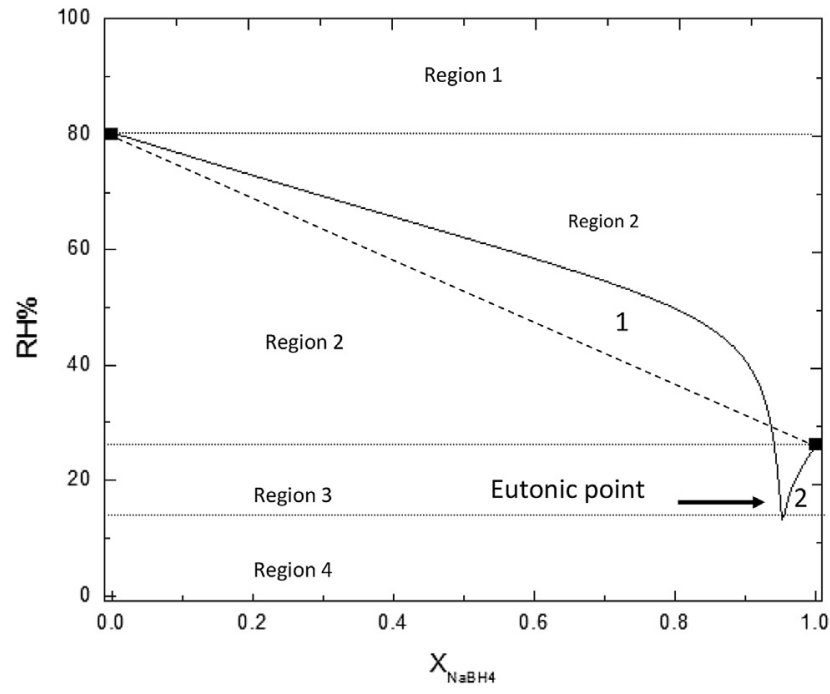

Fig. 3 - Generic illustration of deliquescence lowering and the eutonic composition in a binary mixture of electrolytes. Taken after Carroll et al. [25]. 
production (see Fig. 4 as an example, where the lag time is about $5 \mathrm{~min}$ ). When $\mathrm{CoCl}_{2}$ is added as a catalyst, the lag time is consistently less. Because a higher relative humidity means higher water activity at a given reaction temperature and total pressure, this speeds up dissolution of the solid, which in turn decreases the lag time. In addition, because $\mathrm{CoCl}_{2}$ is a catalyst [16], the combined effect of increased relative humidity and catalytic feature of $\mathrm{CoCl}_{2}$ increases the observed rate of hydrogen release compared to hydrolysis of pure $\mathrm{NaBH}_{4}$.

Fig. 4 shows a typical curve for hydrogen production from $\mathrm{NaBH}_{4}+\mathrm{CoCl}_{2}$ mixture. This particular data was obtained at $90{ }^{\circ} \mathrm{C}$ reactor temperature and $80^{\circ} \mathrm{C}$ saturator temperature. The pathway of steam hydrolysis initiates with deliquescence, followed by dissolution and reaction steps [21]. In Fig. 4, the initial 5 min corresponds to the deliquescence process. After deliquescence completes, dissolution occurs and the $\mathrm{H}_{2}$ is released. The hydrogen flow rate maximizes after nearly $10 \mathrm{~min}$, reaching $0.026 \mathrm{~L} \mathrm{~min}^{-1}$. After the maximum the rate decreases, indicating that $\mathrm{NaBH}_{4}$ is completely dissolved and it is completely consumed after nearly $45 \mathrm{~min}$ of the reaction. Integrating the area under the curve gives the total hydrogen volume generated. For this run, $100 \%$ of the theoretical $\mathrm{H}_{2}$ was achieved.

Fig. 5 shows the normalized $\mathrm{H}_{2}$ yield as a function of various combinations of reactor temperature and saturator temperature. It is generally seen that the $\mathrm{H}_{2}$ yield increases with saturator temperature (that is, with water mole fraction). However, the relative humidity is also a function of the reactor temperature (the temperature at which deliquescence takes place).

Comparing curves 1 and 2 in Fig. 5, where curve 1 is catalyzed by $\mathrm{CoCl}_{2}$ and curve 2 is for pure $\mathrm{NaBH}_{4}$. It is seen that at the beginning of the reaction, curve 2 gives a higher yield than curve 1 . This is because curve 2 has a high relative humidity (69\%) which ensures a faster initiation of the reaction. However, as the reaction continues, curve 1 catches up with curve 2 and its yield and rate surpasses that of curve 2. Finally, the curve 1 achieve $100 \%$ yield earlier than curve 2 . This is because

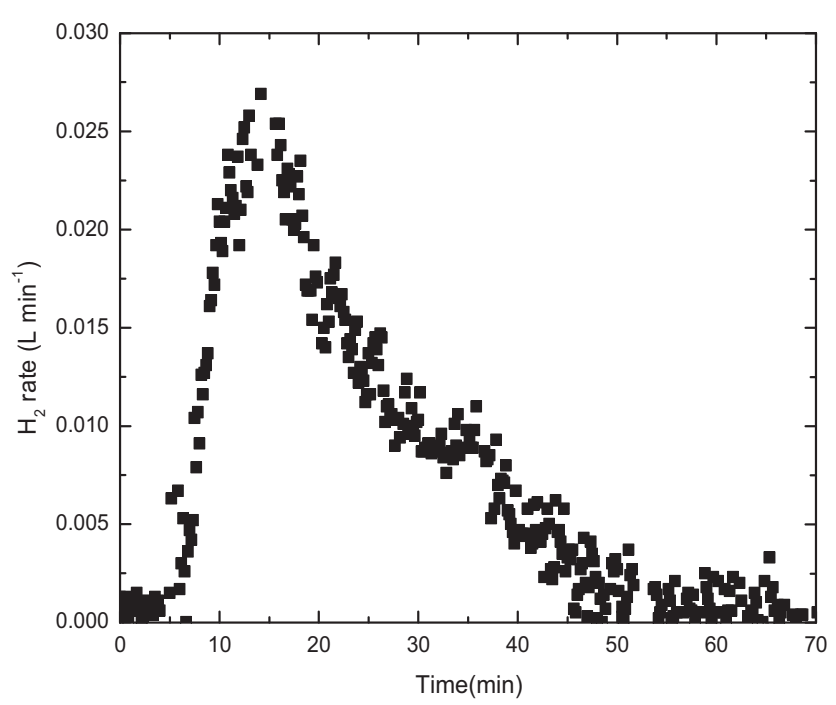

Fig. $4-\mathrm{H}_{2}$ production rate for $0.2 \mathrm{~g} \mathrm{NaBH}_{4}$ with $10 \mathrm{wt} \%$ $\mathrm{CoCl}_{2}$.

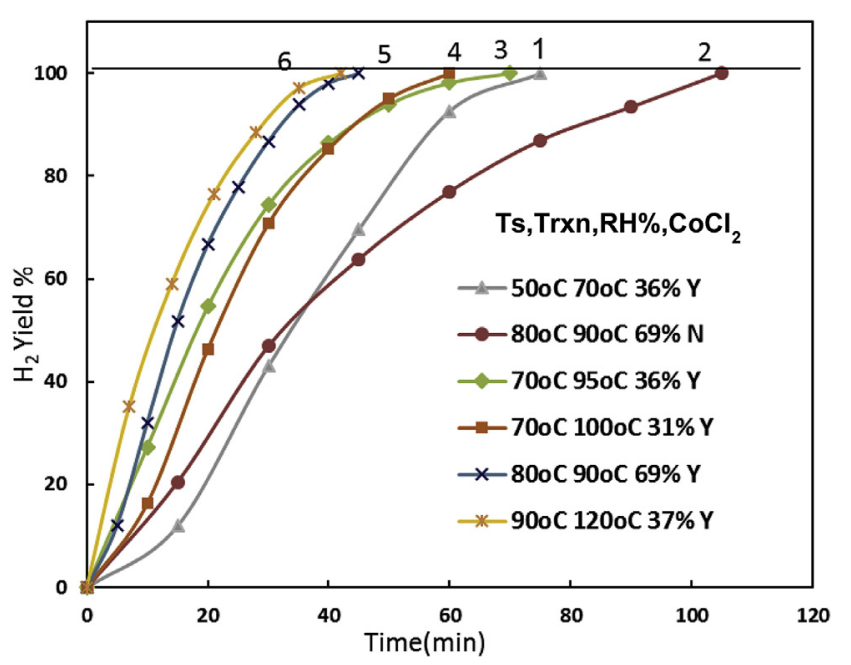

Fig. $5-\mathbf{H}_{2}$ yield at various reaction temperatures and relative humidities.

curve 1 is catalyzed by $\mathrm{CoCl}_{2}$ and catalytic effect outplays the non-catalyzed reaction represented by curve 2 .

Comparing curves 3 and 4, it is seen that curve 3 has a higher yield and rate initially than curve 4 . That is because of a higher relative humidity for the reaction represented by curve 3. So a faster initiation of the deliquescence is seen which gives a higher apparent rate of hydrogen generation. As the reaction continues, the curve 4 catches up when the temperature plays a more important role. At the final stage, the curve 4 exceeds the curve 3 and achieves $100 \%$ yield earlier.

Notice that curve 5 gives faster $\mathrm{H}_{2}$ generation rate than curve 3 , while the reaction temperature is lower for curve 5 $\left(90^{\circ} \mathrm{C}\right)$ than curve $3\left(100^{\circ} \mathrm{C}\right)$. This is because the relative humidity of curve 5 is high ( $\mathrm{RH}=69 \%)$, almost twice the relative humidity of curve $3(\mathrm{RH}=31 \%)$. This indicates that relative humidity is more important than temperature. In addition, by comparing curves 2 and 5, we find that by adding $\mathrm{CoCl}_{2}$ the $\mathrm{H}_{2}$ rate and yield are increased significantly.

Curve $6(\mathrm{RH}=37 \%)$ gives higher rate and yield than curve 5 $(\mathrm{RH}=69 \%)$, and curve 6 achieves complete yield earlier than curve 5 . This indicates that high temperature can be more important than relative humidity for yield and rate in specific reaction condition range.

The above results all show how important it is to consider both reaction temperature and relative humidity (i.e. the water activity) as well as catalyst composition when designing a practical hydrogen generation reactor based on hydrolysis. The combined effect of high reaction temperature and high relative humidity ensures a faster $\mathrm{H}_{2}$ rate and high yield.

\section{Reactor model for $\mathrm{NaBH}_{4}$ steam hydrolysis}

The hydrolysis proceeds first by deliquescence and dissolution of the solids, followed by hydrolysis in the liquid phase [21]. Hydrogen release commences shortly upon deliquescence, but deliquescence continues until the water activity balances in gas and liquid phase and dissolution continues 
Table 2 - Parameters and variables used in the dissolution + reaction model.

\begin{tabular}{lcl} 
Estimated parameters & Value & Unit \\
\hline$k$ & $2.7 \times 10^{-2}$ & $\mathrm{M}^{-1} \mathrm{~s}^{-1}$ \\
$k_{\mathrm{m} 1}$ & $8.0 \times 10^{-3}$ & $\mathrm{~s}^{-1}$ \\
$k_{\mathrm{m} 2}$ & $6.0 \times 10^{-5}$ & $\mathrm{M} \mathrm{s}^{-1}$ \\
\hline
\end{tabular}

until all the solid is dissolved. Based on these physical processes, we propose a two-part model, where the first part deals with dissolution and reaction in parallel, and the second part deals with reaction-only step after the solids are fully dissolved. The model is validated by the experimental data on hydrogen production rate.

\subsection{Two-part dissolution-reaction model}

In order to simplify the processes, we made the following assumptions. We assume that $\mathrm{NaBH}_{4}$ reacts with water only after the amount of condensed water is enough to initiate the dissolution in the deliquescence, i.e. no dissolution and reaction take place at $t=0$; dissolution and reaction occur immediately at $t>0 ; \mathrm{NaBH}_{4}$ concentration is uniform in the liquid phase, i.e. no diffusion in the bulk solution. Considering the mass transfer and reaction, during the dissolution + reaction step, the mass balances of $\mathrm{NaBH}_{4}$ and water and initial conditions are:

$\frac{d C_{\mathrm{NaBH}_{4}}}{\mathrm{dt}}=k_{\mathrm{m} 1}\left(\mathrm{C}_{\mathrm{s}}-\mathrm{C}_{\mathrm{NaBH}_{4}}\right)-\mathrm{kC}_{\mathrm{NaBH}_{4}} \mathrm{C}_{\mathrm{H}_{2} \mathrm{O}}$

$\frac{d C_{\mathrm{H}_{2} \mathrm{O}}}{\mathrm{dt}}=k_{\mathrm{m} 2}\left(a_{\mathrm{v}}-a_{\mathrm{H}_{2} \mathrm{O}}\right)-4 k C_{\mathrm{NaBH}_{4}} C_{\mathrm{H}_{2} \mathrm{O}}$

Initial condition: $t=0, C_{\mathrm{NaBH}_{4}}=0 ; C_{\mathrm{H}_{2} \mathrm{O}}=55.5\left(\mathrm{~mol} \mathrm{~L}^{-1}\right)$;

In Eqs. (1) and (2), the rate of change of $\mathrm{NaBH}_{4}$ and water are affected by the rate of $\mathrm{NaBH}_{4}$ and water transfer from solid and vapor phase, respectively, to solution as well as hydrolysis reaction rate. Because water has significant influence in the kinetics of steam hydrolysis, as will be proved later in the modeling result, we incorporated the water concentration in the reaction term. $\mathrm{C}_{\mathrm{NaBH}_{4}}$ represents $\mathrm{NaBH}_{4}$ concentration in solution and $\mathrm{C}_{\mathrm{H}_{2} \mathrm{O}}$ represents water concentration in solution. $C_{\mathrm{s}}$ is solid $\mathrm{NaBH}_{4}$ concentration $(28.3 \mathrm{M})$ in solid phase and $a_{\mathrm{v}}$ is water vapor activity in gas phase. The $a_{\mathrm{H}_{2} \mathrm{O}}$ is water activity in liquid solution. Here, we use the experiment at $90^{\circ} \mathrm{C}$ to model the $\mathrm{H}_{2}$ evolution reaction. Table 2 lists parameters for the ordinary differential equations. According to the definition of activity, a pure species is used as reference. The water activity $a_{\mathrm{v}}$ is calculated as water partial pressure in gas phase divided by pure water saturated pressure at the same temperature; According to $\mathrm{N}_{2}+$ steam gas mixture data from OLI database [2], water mole fraction is about 0.68 at $90^{\circ} \mathrm{C}$. The total gas pressure is $1 \mathrm{~atm}$ for our experiment. Hence, $0.69 \mathrm{~atm}$ is used for the partial pressure of steam. The saturated steam pressure in air at $90^{\circ} \mathrm{C}$ is $0.69 \mathrm{~atm}$. Because steam in air and steam in $\mathrm{N}_{2}$ could be approximately considered to be same, we calculated that the water activity is nearly 1 . Meanwhile, water concentration is converted to water activity $\mathrm{a}_{\mathrm{H} 2 \mathrm{O}}$ in terms of its concentration in solution divided by pure liquid water concentration of $55.5 \mathrm{~mol} \mathrm{~L}^{-1}$.

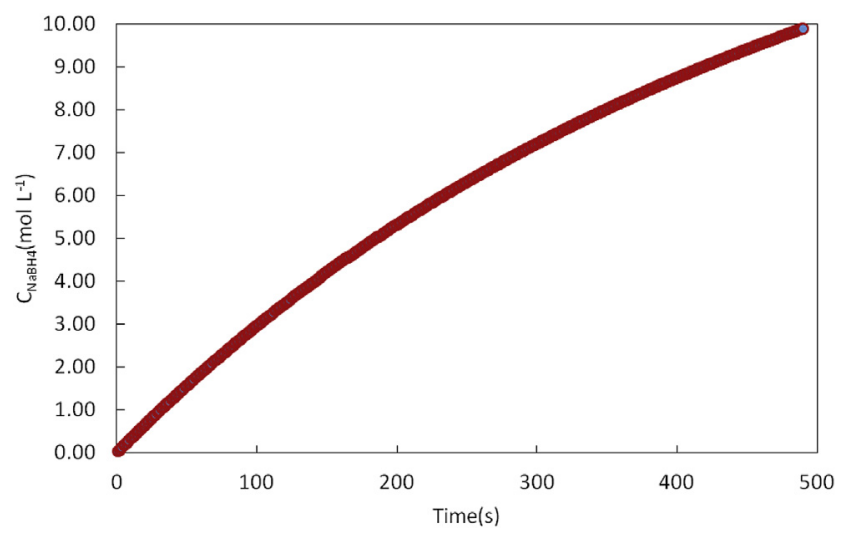

Fig. $6-\mathrm{NaBH}_{4}$ aqueous concentration profile for the dissolution + reaction step.

The rate constant is $k$, and mass transfer coefficient for solid to liquid phase is $k_{\mathrm{m} 1}$ and for gas to liquid phase is $k_{\mathrm{m} 2}$. The estimated values for each variable are given in the table. The estimated rate constant $k$ is $2.7 \times 10^{-2} \mathrm{M}^{-1} \mathrm{~s}^{-1}$. A typical value of $k$ of hydrolysis in un-buffered or buffered water solution is $10^{-9}-10^{-7} \mathrm{M}^{-1} \mathrm{~s}^{-1}$ at $25^{\circ} \mathrm{C}$ [23]. The estimated rate constant $k$ is larger because the reaction is conducted at higher temperature and the rate constant also includes the catalytic effect of $\mathrm{CoCl}_{2}$. The mass transfer coefficients $k_{\mathrm{m} 1}$ and $k_{\mathrm{m} 2}$ are both estimated by fitting the model with experimental data. It is found that coefficients $k_{\mathrm{m} 1}$ is $8.0 \times 10^{-3} \mathrm{~s}^{-1}$ and $k_{\mathrm{m} 2}$ is $6.0 \times 10^{-5} \mathrm{M} \mathrm{s}^{-1}$.

When the solid $\mathrm{NaBH}_{4}$ is dissolved, the process enters the reaction-only step. The governing equations become (3) and (4):

$\frac{d C_{\mathrm{NaBH}_{4}}}{\mathrm{dt}}=-k \mathrm{C}_{\mathrm{NaBH}_{4}} \mathrm{C}_{\mathrm{H}_{2} \mathrm{O}}$

$\frac{d C_{\mathrm{H}_{2} \mathrm{O}}}{\mathrm{dt}}=k_{\mathrm{m} 2}\left(a_{\mathrm{v}}-a_{\mathrm{H}_{2} \mathrm{O}}\right)-4 k \mathrm{C}_{\mathrm{NaBH}_{4}} \mathrm{C}_{\mathrm{H}_{2} \mathrm{O}}$

Eqs. (1)-(4) are solved numerically in Maple12.

\subsection{Results and discussions}

The computed $\mathrm{NaBH}_{4}$ concentration during the dissolution + reaction step is shown in Fig. 6 . It is seen that the

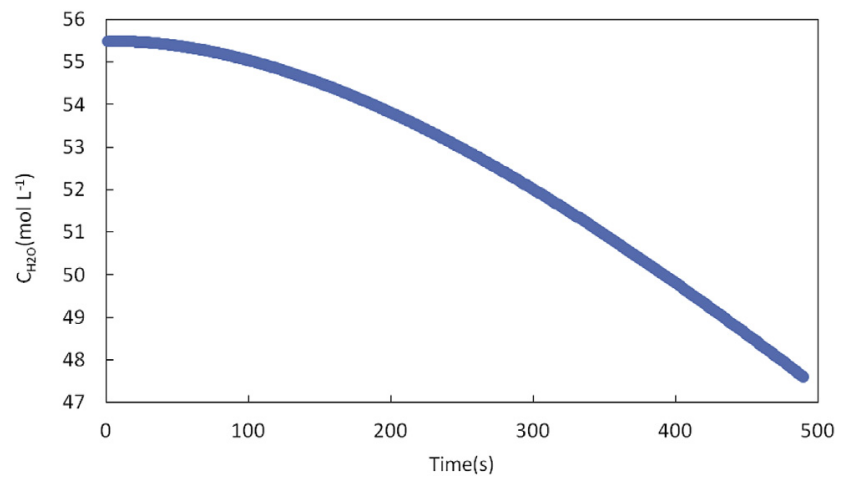

Fig. $7-\mathrm{H}_{2} \mathrm{O}$ concentration profile for the dissolution + reaction step. 


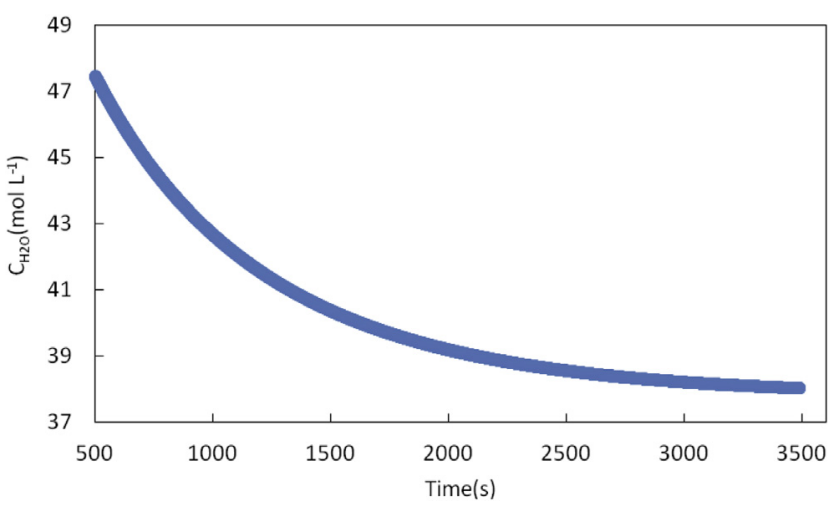

Fig. $9-\mathrm{H}_{2} \mathrm{O}$ concentration profile for the reaction-only step.

concentration of $\mathrm{NaBH}_{4}$ increases until dissolution is complete. At about $490 \mathrm{~s}$, the $\mathrm{NaBH}_{4}$ solid is completely dissolved. The maximum concentration is $9.78 \mathrm{~mol} \mathrm{~L}^{-1}$. This confirms our assumption that steam hydrolysis is conducted in highly concentrated solution. Meanwhile, the corresponding water concentration decreases from $55.5 \mathrm{~mol} \mathrm{~L}^{-1}$ to $47.6 \mathrm{~mol} \mathrm{~L}^{-1}$, as shown in Fig. 7.

When the solids are completely dissolved, there remains only chemical reaction in the aqueous phase. This is the reaction-only step, shown in Figs. 8 and 9. It is seen that after another $3000 \mathrm{~s}$, the concentration of $\mathrm{NaBH}_{4}$ reaches zero, indicating complete reaction. Meanwhile, the concentration of water drops to $38.1 \mathrm{~mol} \mathrm{~L}^{-1}$. The decrease of water concentration is because the consumption of water accelerates during the reaction-only step and water consumption continues for longer time than in the dissolution + reaction step.

A comparison between modeling data and experimental data is shown in Fig. 10. The left curve represents dissolution + reaction process and the right fitting curve represents reaction-only step. From $t=0$, the solid starts to dissolve while the reaction initiates. Because dissolution dominates at this stage, the $\mathrm{NaBH}_{4}$ concentration keeps increasing. After $490 \mathrm{~s}$, the $\mathrm{NaBH}_{4}$ completely dissolved, where a maximum is seen. Subsequently there is only $\mathrm{NaBH}_{4}$ hydrolysis in liquid solution. The agreement of the model with experimental data validated our two-part dissolution + reaction model.

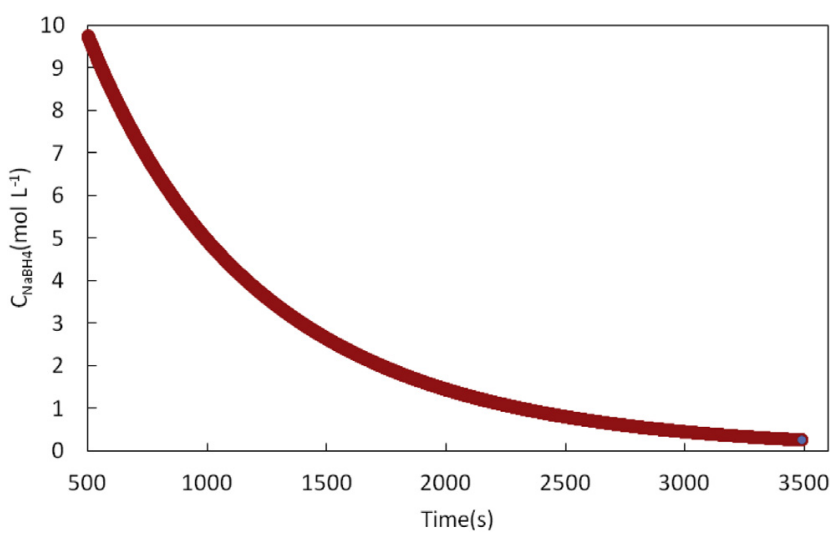

Fig. $8-\mathrm{NaBH}_{4}$ concentration profile for the reaction-only step.

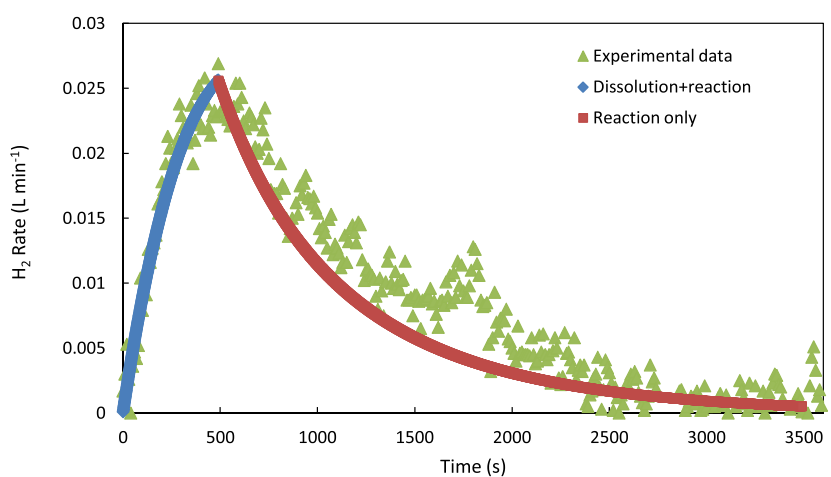

Fig. 10 - Model fitting for the experimental data of steam hydrolysis at $90{ }^{\circ} \mathrm{C}\left(0.2 \mathrm{~g} \mathrm{NaBH}_{4}, 10 \mathrm{wt} . \% \mathrm{CoCl}_{2}\right)$.

\section{Conclusion}

This study determines for the first time the region of temperature and relative humidity under which deliquescence of $\mathrm{NaBH}_{4}$ and $10 \% \mathrm{CoCl}_{2}$ mixture is favored. Deliquescence is a necessary first step for release of hydrogen. $\mathrm{CoCl}_{2}$ accelerates the reaction because of both as a catalyst and its effect on increasing DRH (compared to pure $\mathrm{NaBH}_{4}$ ). The $\mathrm{H}_{2}$ generation rate affected by both reaction temperature and relative humidity is revealed. Combining high reaction temperature and high relative humidity contributes to accelerated steam hydrolysis. A two-part reactor model accounting for deliquescence, solid dissolution, and hydrolysis to release $\mathrm{H}_{2}$ is established for $\mathrm{NaBH}_{4}$ steam hydrolysis, with reasonable estimated kinetic constant and mass transfer coefficients.

\section{Acknowledgment}

This work is supported by NSF CBET 0756089 . We acknowledge helpful discussion with Dr. Karl Johnson from University of Pittsburgh.

\section{R E F E R E N C E S}

[1] Turner JA. A realizable renewable energy future (vol 285, pg 687, 1999). Science 1999;285:1493.

[2] Zhang R, Weidner JW. Analysis of a gas-phase Br-2-H-2 redox flow battery. J Appl Electrochem 2011;41(10):1245-52.

[3] Stockmayer WH, Rice DW, Stephenson CC. Thermodynamic properties of sodium borohydride and aqueous borohydride ion. J Am Chem Soc 1955;77(7):1980-3.

[4] Zheng J, Kai K, Liu Z, Chen C, Ma X. Lightweight highpressure hydrogen tank. J Chem Ind Eng 2004;55:130-3.

[5] Atkinson K, Roth S, Hirscher M, Grunwald W. Carbon nanostructures: an efficient hydrogen storage medium for fuel cells. Fuel Cells Bull 2001;38:9-12.

[6] Rosi NL, Eckert J, Eddaoudi M, Vodak DT, Kim J, Keeffe MO, et al. Hydrogen storage in microporous metal-organic frameworks. Science 2003;300:1127-9.

[7] Kojima Y, Kawai Y, Nakanishi H, Matsumoto S. Compressed hydrogen generation using chemical hydride. J Power Sources 2004;135(1-2):36-41. 
[8] George L, Saxena SK. Structural stability of metal hydrides, alanates, and borohydrides of alkali and alkali-earth elements: a review. Int J Hydrogen Energy 2010;35(11): 5454-70.

[9] Santos DMF, Sequeira CAC. Sodium borohydride as a fuel for the future. Renew Sustain Energy Rev 2011;15(8): 3980-4001.

[10] Amendola SC, Sharp-Goldman SL, Janjua MS, Spencer NC, Kelly MT, Petillo PJ, et al. A safe, portable, hydrogen gas generator using aqueous borohydride solution and $\mathrm{Ru}$ catalyst. Int J Hydrogen Energy 2000;25:969-75.

[11] Demirci UB, Akdim O, Miele P. Ten-year efforts and a no-Go recommendation for sodium borohydride for on-board automotive hydrogen storage. Int J Hydrogen Energy 2009;34:2638-45.

[12] Bai Y, Wu C, Wu F, Yi B. Carbon-supported platinum catalysts for on-site hydrogen generation from $\mathrm{NaBH}_{4}$ solution. Mater Lett 2006;60:2236-9.

[13] Guella G, Zanchetta C, Patton B, Miotello A. New insights on the mechanism of palladium-catalyzed hydrolysis of sodium borohydride from B-11 NMR measurements. J Phys Chem B 2006;110:17024-33.

[14] Krishnan P, Yang TH, Lee WY, Kim CS. PtRu-LiCoO 2 - an efficient catalyst for hydrogen generation from sodium borohydride solutions. J Power Sources 2005;143:17-23.

[15] Holbrook KA, Twist PJ. Hydrolysis of the borohydride ion catalysed by metal-boron alloys. J Am Chem Soc A 1971:890-4.
[16] Kaufman CM, Sen B. Hydrogen generation by hydrolysis of sodium tetrahydroborate: effects of acids and transition metals and their salts. ACS Dalton Trans 1985:307-13.

[17] Aiello R, Sharp JH, Matthews MA. Production of hydrogen from chemical hydrides via hydrolysis with steam. Int $J$ Hydrogen Energy 1999;24(12):1123-30.

[18] Marrero-Alfonso EY, Gray JR, Davis TA, Matthews MA. Minimizing water utilization in hydrolysis of sodium borohydride: the role of sodium metaborate hydrates. Int $\mathrm{J}$ Hydrogen Energy 2007;32(18):4723-30.

[19] Marrero-Alfonso EY, Gray JR, Davis TA, Matthews MA. Hydrolysis of sodium borohydride with steam. Int J Hydrogen Energy 2007;32(18):4717-22.

[20] Marrero-Alfonso EY, Beaird AM, Davis TA, Matthews MA. Hydrogen generation from chemical hydrides. Ind Eng Chem Res 2009;48:3703-12.

[21] Beaird AM, Davis TA, Matthews MA. Deliquescence in the hydrolysis of sodium borohydride by water vapor. Ind Eng Chem Res 2010;49(20):9596-9.

[22] Russell AP, Fletcher KS. Optical sensor for the determination of moisture. Anal Chim Acta 1985;170:209.

[23] Gardiner JA, Collat JW. Kinetics of the stepwise hydrolysis of tetrahydroborate ion. J Am Chem Soc 1965;87(8):1692-700.

[24] Wexler AS, Seinfeld JH. Second-generation inorganic aerosol model. Atmos Environ A Gen 1991;25 A:2731.

[25] Carroll S, Craig L, Wolery TJ. Deliquescence of NaCl- $\mathrm{NaNO}_{3}$, $\mathrm{KNO}_{3}-\mathrm{NaNO}_{3}$, and $\mathrm{NaCl}-\mathrm{KNO}_{3}$ salt mixtures from 90 to $120^{\circ} \mathrm{C}$. Geochem Trans 2005;6:19. 